\title{
PENGARUH MENGONSUMSI AIR KELAPA (COCOS NUCIFERA) TERHADAP pH SALIVA PADA MASYARAKAT DESA WATU KECAMATAN MARIORIWAWO KABUPATEN SOPPENG
}

\author{
R. Ardian Priyambodo, Rizka Rahmadani
}

\begin{abstract}
ABSTRAK
Saliva merupakan salah satu faktor yang berperan terhadap perkembangan karies. Saliva mempengaruhi proses terjadinya karies karena saliva selalu membasahi gigi geligi sehingga mempengaruhi lingkungan dalam rongga mulut. Derajat Keasaman $(\mathrm{pH})$ saliva merupakan salah satu faktor penting yang berperan dalam karies gigi, kelainan periodontal, dan penyakit lain di rongga mulut. Kadar derajat keasaman $(\mathrm{pH})$ saliva yang normal di dalam mulut berada di angka 7 dan bila nilai $\mathrm{pH}$ saliva jatuh $\leq 5,5$ berarti keadaannya sudah sangat kritis. Buah kelapa muda merupakan salah satu produk tanaman tropis yang unik karena disamping komponen daging buahnya dapat langsung dikonsumsi, juga komponen air buahnya dapat langsung diminum tanpa melalui pengolahan. Air kelapa muda, sudah sejak lama dikenal sebagai minuman yang menyehatkan dan sebagai minuman yang banyak khasiatnya. Letaknya yang terlindung oleh tempurung keras dan sabut kelapa yang tebal, membuat air kelapa menjadi minuman steril, bebas dari segala bentuk kontaminasi, serta mengandung gula reduksi, kalium, natrium, kalsium, vitamin $\mathrm{C}$ dengan $\mathrm{pH}$ 5,5. Penelitian ini bertujuan untuk mengetahui pengaruh mengonsumsi air kelapa muda terhadap perubahan $\mathrm{pH}$ saliva. Jenis penelitian ini adalah true experimental design dengan pretest and post test group design. Sampel penelitian ini sebanyak 30 orang. Pengukuran $\mathrm{pH}$ saliva dilakukan sebanyak dua kali pada tiap sampel, yaitu saliva normal dan saliva setelah meminum air kelapa. Pengumpulan saliva dengan metode spitting dan pengukuran $\mathrm{pH}$ saliva menggunakan $\mathrm{pH}$ meter digital. Hasil penelitian mendapatkan air kelapa dapat menurunkan derajat $\mathrm{pH}$ saliva karena $\mathrm{pH}$ kelapa yang bersifat asam.
\end{abstract}

Kata kunci : karies, kelapa, pH saliva

\section{PENDAHULUAN}

Saliva merupakan salah satu faktor yang berperan terhadap perkembangan karies. Saliva mempengaruhi proses terjadinya karies karena saliva selalu membasahi gigi geligi sehingga mempengaruhi lingkungan dalam rongga mulut. Derajat Keasaman $(\mathrm{pH})$ saliva merupakan salah satu faktor penting yang berperan dalam karies gigi, kelainan periodontal, dan penyakit lain di rongga mulut. Kadar derajat keasaman $(\mathrm{pH})$ saliva yang normal di dalam mulut berada di angka 7 dan bila nilai $\mathrm{pH}$ saliva jatuh $\leq 5,5$ berarti keadaannya sudah sangat kritis. Nilai pH saliva berbanding terbalik, di mana makin rendah nilai $\mathrm{pH}$ makin banyak asam dalam larutan, sebaliknya makin meningkatnya nilai pH berarti bertambahnya sifat basa dalam larutan. Pada $\mathrm{pH} 7$, tidak ada keasaman atau kebasaan larutan, dan ini disebut netral. Pertumbuhan bakteri terjadi pada $\mathrm{pH}$ saliva yang optimum berkisar 6,5-7,5 dan bila rongga mulut $\mathrm{pH}$ salivanya rendah $(4,5-5,5)$ akan memudahkan pertumbuhan kuman asidogenik seperti
Streptococcus mutans dan Lactobacillus. Derajat keasaman $(\mathrm{pH})$ saliva merupakan bagian yang penting dalam meningkatkan integritas gigi karena dapat meningkatkan terjadinya remineralisasi, dimana penurunan $\mathrm{pH}$ saliva dapat menyebabkan demineralisasi gigi. Adanya proses remineralisasi yang akan menurunkan kemungkinan terjadinya karies. Remineralisasi adalah suatu proses dimana permukaan gigi akan memperoleh mineral kembali (Suratri, 2017).

Kelapa yang memiliki nama latin Cocos nucifera merupakan salah satu tanaman yang mudah ditemui dan dikonsumsi di Indonesia termasuk Sulawesi Selatan karena memiliki iklim tropis. Buah kelapa terdiri dari daging dan air kelapa. Air kelapa muda, sudah sejak lama dikenal sebagai minuman yang menyehatkan. Letaknya yang terlindung oleh tempurung keras dan sabut kelapa yang tebal, membuat air kelapa menjadi minuman steril, bebas dari segala bentuk kontaminasi, serta mengandung gula reduksi, 
kalium, natrium, kalsium, vitamin $\mathrm{C}$ dengan $\mathrm{pH}$ 5,5 (Mokoginta, 2017).

Buah kelapa muda merupakan salah satu produk tanaman tropis yang unik karena di samping komponen daging buahnya dapat langsung dikonsumsi, juga komponen air buahnya dapat langsung diminum tanpa melalui pengolahan. Keunikan ini ditunjang oleh sifat fisik dan komposisi kimia daging dan air kelapa, sehingga produk ini sangat digemari konsumen baik anak-anak maupun orang dewasa. Air kelapa muda termasuk minuman yang alami dan higienis serta memiliki komposisi gizi yang cukup baik. Oleh karena itu dengan minum air kelapa muda selain dapat memenuhi rasa haus juga dapat mengurangi rasa lapar dalam jangka beberapa waktu dan menyembuhkan beberapa jenis penyakit. Air kelapa muda dikenal sebagai minuman yang banyak khasiatnya, seperti membunuh cacing perut, minuman yang baik bagi penderita kolera (Woodroof, 1979)

Selanjutnya air kelapa muda memiliki unsur kalium (K) yang tertinggi, mencapai 7.300 $\mathrm{mg} / \mathrm{l}$. Oleh karena itu air kelapa muda berperan penting dalam meningkatkan frekuensi buang air kencing dan membantu mengeliminasi obat-obat dan antibodi-antibodi lain yang biasanya digunakan pada kasus-kasus infeksi.

Selain itu membantu mempercepat absorpsi obat-obat dengan cara mempercepat konsentrasinya dalam darah dan juga sebagai penangkal penyakit-penyakit yang disebabkan oleh kecanduan alkohol dan merokok (Barlina, 2004). Selain itu, secara alami, air kelapa muda mempunyai komposisi mineral dan gula yang sempurna sehingga mempunyai kesetimbangan elektrolit yang sempurna, sama dengan cairan tubuh manusia (Prasetyo, 2002).

\section{METODE PENELITIAN}

Jenis penelitian ini ialah true experimental design dengan pretest and post test group design yang bertujuan untuk mengetahui pengaruh air kelapa terhadap $\mathrm{pH}$ saliva. Penelitian ini dilakukan di Desa Watu kecamatan Marioriwawo Kabupaten Soppeng. Waktu penelitian dilakukan pada bulan April-Juni 2019. Populasi dalam penelitian ini adalah seluruh warga desa berjumlah 3041 jiwa. Pengambilan sampel secara accidental sampling yaitu mengambil sampel yang kebetulan ditemui pada saat itu. Jumlah sampel yang diambil sebanyak 30 orang. Penilaian $\mathrm{pH}$ saliva, yaitu larutan bersifat asam jika $\left(\mathrm{H}_{+}\right)<(0-)$ atau $\mathrm{pH}<7$, bersifat netral jika $\left(\mathrm{H}_{+}\right)=\left(\mathrm{HO}^{-}\right)$atau $\mathrm{pH}=7$ dan bersifat basa jika $(\mathrm{H}+)>(\mathrm{H}-)$ atau $\mathrm{pH}>7$.

Tahap pengukuran dengan cara mengambil sampel cairan yang akan diukur kadar pHnya dan diletakkan dalam wadah, memasukkan $\mathrm{pH}$ meter kedalam wadah yang berisi cairan yang akan diuji. Pada saat dicelupkan kedalam cairan, skala angka akan bergerak acak, ditunggu hingga angka tersebut berhenti dan tidak berubah-ubah dana hasil akan terlihat pada display digital $\mathrm{pH}$ meter.

Sebelumnya pada subyek telah diinstruksikan untuk tidak mengonsumsi makanan dan minuman satu jam sebelum penelitian dilakukan lalu diinstruksikan meminum air mineral sebanyak $220 \mathrm{ml}$. Setelah itu, subjek diminta mengumpulkan saliva pada pot penampung saliva dengan meludahkan saliva dengan teknik spitting, yaitu saliva dibiarkan mengumpul di dasar mulut dengan menundukkan kepala, tidak menggerakkan lidah, menjaga bibirnya tetap tertutup dan tidak melakukan gerakan menelan, lalu subjek diinstruksikan untuk meludah dan ditampung dalam pot penampung saliva. Selanjutnya $\mathrm{pH}$ saliva diukur menggunakan $\mathrm{pH}$ meter untuk mengetahui $\mathrm{pH}$ saliva normal dari masing-masing subyek. Subjek kemudian diinstruksikan untuk meminum air kelapa sebanyak $220 \mathrm{ml}$ sampai habis; 5 menit kemudian, saliva dikumpulkan dalam pot penampung saliva dan diukur pHnya untuk 
mengetahui $\mathrm{pH}$ saliva akhir setelah diberikan perlakuan. $\mathrm{pH}$ saliva kemudian dicatat dan hasilnya diolah kemudian disajikan dalam bentuk tabel lalu dilakukan uji paired t-test. Analisis data ini dilakukan dengan membuat uraian secara sistematis mengenai hasil penelitian kemudian mendistribusikannya dalam bentuk tabel dan melakukan uji Paired T-test dengan menggunakan SPSS 22.0 for windows. Uji ini biasa dilakukan pada sampel yang diamati sebelum dan sesudah perlakuan. Gunanya untuk mengetahui ada atau tidaknya perubahan antara sampel yang diamati sebelum dan sesudah perlakuan
HASIL

Tabel 1 menunjukkan bahwa berdasarkan jenis kelamin, jumlah responden yang berjenis kelamin perempuan dan laki laki adalah sama yaitu sebanyak 15 orang. Sedangkan berdasarkan umur responden terdiri dari responden yang berusia $<20$ tahun sebanyak 4 orang, responden yang berusia 20 -25 tahun sebanyak 17 orang, responden yang berusia 26 - 30 tahun sebanyak 7 orang, dan responden yang berusia $>30$ tahun sebanyak 2 orang. Sehingga responden dalam penelitian ini didominasi oleh responden yang berusia 20-25 tahun yaitu sebanyak 17 orang.

Tabel 1

Karakteristik Reponden

\begin{tabular}{|l|c|}
\hline \multicolumn{1}{|c|}{ Karakteristik Reponden } & Jumlah Responden \\
\hline $1 . \quad$ Jenis Kelamin & 15 \\
Laki-Laki & 15 \\
Perempuan & 30 \\
\hline Total & \\
\hline $2 . \quad$ Umur & 4 \\
$<20$ tahun & 17 \\
$20-25$ tahun & 7 \\
$26-30$ tahun & 2 \\
$>30$ tahun & 30 \\
\hline Total & \\
\hline
\end{tabular}

.Tabel 2

pH Saliva Sebelum Mengonsumsi Air Kelapa

\begin{tabular}{|c|c|}
\hline $\begin{array}{c}\mathrm{pH} \text { Saliva Sebelum Mengonsumsi Air } \\
\text { Kelapa }\end{array}$ & Jumlah Responden \\
\hline 6.47 & 1 \\
\hline 6.50 & 2 \\
\hline 6.78 & 2 \\
\hline 6.80 & 1 \\
\hline 6.82 & 2 \\
\hline 6.90 & 4 \\
\hline 7.00 & \\
\hline
\end{tabular}




\begin{tabular}{|c|c|}
\hline $\begin{array}{c}\text { pH Saliva Sebelum Mengonsumsi Air } \\
\text { Kelapa }\end{array}$ & Jumlah Responden \\
\hline 7.10 & 4 \\
\hline 7.20 & 4 \\
\hline 7.21 & 1 \\
\hline 7.24 & 1 \\
\hline 7.29 & 5 \\
\hline 7.30 & 1 \\
\hline 7.40 & 30 \\
\hline Total & \\
\hline
\end{tabular}

Pada tabel di atas menunjukkan bahwa pH saliva terendah sebelum mengonsumsi air kelapa adalah 6,47, sedangkan yang tertinggi adalah 7,40.

Tabel 3

pH Saliva Sesudah Mengonsumsi Air Kelapa

\begin{tabular}{|c|c|}
\hline $\begin{array}{c}\text { pH Saliva Sesudah } \\
\text { Mengonsumsi Air Kelapa }\end{array}$ & Jumlah Responden \\
\hline 6.0 & 1 \\
\hline 6.2 & 1 \\
\hline 6.3 & 2 \\
\hline 6.4 & 4 \\
\hline 6.5 & 4 \\
\hline 6.6 & 1 \\
\hline 6.7 & 2 \\
\hline 6.8 & 3 \\
\hline 6.9 & 6 \\
\hline 7.0 & 5 \\
\hline 7.1 & 30 \\
\hline Total & \\
\hline & \\
\hline
\end{tabular}

Sedangkan pada Tabel 3, menunjukkan bahwa pH saliva terendah setelah mengonsumsi air kelapa adalah 6,00 , sedangkan yang tertinggi adalah 7,10. Hal ini membuktikan bahwa setelah mengkonsumsi air kelapa, $\mathrm{pH}$ saliva responden berkurang.

Tabel 4

Rata-rata pH Saliva

\begin{tabular}{|c|c|c|c|}
\hline & $\begin{array}{c}\text { Rata-rata pH } \\
\text { Saliva }\end{array}$ & $\begin{array}{c}\text { Jumlah } \\
\text { Responden }\end{array}$ & $\begin{array}{c}\text { Nilai } \\
\text { Signifikan }\end{array}$ \\
\cline { 1 - 3 } pH Saliva Sebelum pemberian air kelapa & 7,0737 & 30 & \multirow{2}{*}{0,003} \\
\cline { 1 - 2 } pH Saliva Sesudah pemberian air kelapa & 6,8800 & 30 & \\
\cline { 1 - 2 }
\end{tabular}


Tabel 4 menunjukkan bahwa rata-rata $\mathrm{pH}$ saliva pada saat sebelum pemberian air kelapa adalah 7,0737 . Sedangkan pada sesudah pemberian air kelapa rata-ratanya menjadi 6,8800, ada penurunan rata-rata $\mathrm{pH}$ saliva pada respoden setelah mengkonsumsi air kelapa. Hasil uji statistik yang didapatkan $p=0,003(p<0,05)$ yang artinya ada perbedaan yang signifikan $\mathrm{pH}$ saliva sebelum dan setelah tes.

\section{PEMBAHASAN}

Hasil penelitian yang dilakukan pada masyarakat Desa Watu Kecamatan Marioriwawo Kabupaten Soppeng sebanyak 30 orang, diperoleh responden dengan karakteristik lakilaki dan perempuan memiliki jumlah yang sama banyak. Jumlah responden yang berjenis kelamin perempuan dan laki laki adalah sama yaitu sebanyak 15 orang. Penelitian ini dilakukan untuk mengetahui pengaruh konsumsi air kelapa terhadap $\mathrm{pH}$ saliva pada masyarakat Desa Watu Kecamatan Marioriwawo Kabupaten Soppeng. Hasil penelitian yang dilakukan pada masyarakat sebelum dan setelah mengonsumsi air kelapa didapatkan saliva mengalami penurunan $\mathrm{pH}$ ke asam. Terjadinya perubahan $\mathrm{pH}$ saliva dipengaruhi oleh beberapa faktor, antara lain diet karbohidrat, irama sikardian, kapasitas buffer, laju aliran saliva dan perangsangan kecepatan sekresi.

Makanan dan minuman yang dikonsumsi dapat menyebabkan saliva bersifat asam maupun basa. Konsumsi air kelapa muda dapat menurunkan $\mathrm{pH}$ saliva. Terjadinya penurunan $\mathrm{pH}$ setelah mengonsumsi air kelapa dikarenakan air kelapa muda memiliki $\mathrm{pH}$ rendah yaitu 5,5 , dan kandungan ion-ion dalamnya bersifat asam seperti vitamin $\mathrm{C}$, total padatan atau asam laktat, serta gula reduksi yang terdiri dari fruktosa, glukosa, dan asam amino (Runtunuwu, 2011). Asam-asam organik yang terdapat pada air kelapa ini dapat memengaruhi perubahan $\mathrm{pH}$ saliva. Semakin banyak sumber asam-asam organik yang dapat dimetabolisme, maka semakin menurun pH saliva (Yanwar SE, 2015). lonisasi asam laktat akan menghasilkan ion $\mathrm{H}_{+}$ sehingga menyebabkan suasana asam pada saliva. Asam laktat membentuk asiditas ekstra sehingga menurunkan $\mathrm{pH}$ kemudian menyebabkan terlepasnya ion kalsium dan fosfat dari enamel gigi, selanjutnya dapat menyebabkan terbentuknya kavitas pada enamel (Waworuntu, 2014).

Setelah mengonsumsi makanan atau minuman yang bersifat basa seperti air jeruk nipis, teh, madu, buah-buahan, sayur-sayuran berwarna hijau dan kuning, serta sayuran berumbi disarankan agar mengonsumsi air kelapa muda setelah itu agar supaya $\mathrm{pH}$ saliva kembali ke nilai normal. Tetapi tidak dengan makanan yang bersifat asam seperti telur, daging, ikan, makanan laut, unggas, makanan gorengan, biji-bijian yang diputihkan seperti beras putih, roti putih atau terigu, mie putih; makanan olahan, gula putih, kopi, dan minuman berkarbonasi lalu setelah itu mengonsumsi air kelapa muda karena dapat membuat $\mathrm{pH}$ saliva semakin turun.

Pada hasil pengukuran $\mathrm{pH}$ saliva minimal setelah mengonsumsi air kelapa muda pada penelitaian ini menunjukkan bahwa penurunan $\mathrm{pH}$ saliva tidak sampai pada $\mathrm{pH}$ kritis yaitu $<5,5$. Pengukuran $\mathrm{pH}$ saliva pada penelitian ini langsung diukur setelah responden selesai mengonsumsi air kelapa muda atau langsung setelah terstimulasi dengan maksud tidak memberikan rentang waktu pada proses kapasitas buffer untuk bekerja. Terjadinya penurunan $\mathrm{pH}$ saliva selama 1-3 menit oleh asam akan membuat enzim bicarbonate anhydrase mengakatalis reaksi ion $\mathrm{H}+$ bebas dari ion bikarbonat dan reaksi itu akan menghasilkan aquades serta karbondioksida yang akan dilepas ke rongga mulut, sehingga $\mathrm{pH}$ saliva secara perlahan akan naik pada 15 menit kemudian dan akan kembali ke pH normal pada 30-60 menit (Amalia, 2013 ; Cholid, 2015 ; Adzakiyah, 2016). 
Ini sependapat dengan hasil penelitian ekstrak teh hijau 3\% yang dikumur selama tiga menit lebih meningkatkan sekresi, $\mathrm{pH}$ dan kadar bikarbonat saliva dibanding satu menit dan dua menit pada tahun 2014 yang menunjukkan peningkatan sekresi, $\mathrm{pH}$ dan kadar bikarbonat saliva sudah terjadi pada satu sampai dua menit, tetapi lebih meningkatkan tiga menit (Hervina, 2014).

Kandungan air yang cukup tinggi dalam buah kelapa dapat membantu fungsi saliva dalam pembersihan rongga mulut, sehingga dapat menghambat pertumbuhan plak, karena natrium dapat digunakan sebagai kontrol plak (Lewpadang, 2015). Kalsium dan magnesium yang dapat mengurangi ketegangan otot dan vitamin C merupakan zat alami anti inflamasi yang dapat membantu meringankan rasa sakit akibat nyeri. Hal ini sejalan dengan hasil penelitian tentang pengaruh pemberian air kelapa hijau terhadap tingkat nyeri haid pada perempuan yang sedang mengalami nyeri haid di Yogyakarta bahwa air kelapa hijau dapat mengurangi tingkat nyeri haid dan termasuk juga pada saat sakit gigi (Lestari, 2015).

Berdasarkan uji $t$-paired pada $\mathrm{pH}$ saliva sebelum dan sesudah mengonsumsi air kelapa muda pada Tabel 3 menunjukkan hasil dengan nilai signifikansi yang didapatkan yaitu 0,003 lebih kecil dari nilai probabilitas 0,05. Hasil tersebut menunjukkan terdapat perbedaan yang bermakna pada $\mathrm{pH}$ saliva sebelum dan sesudah mengonsumsi dengan air kelapa muda atau dapat dikatakan bahwa terdapat pengaruh mengonsumsi air kelapa terhadap perubahan $\mathrm{pH}$ saliva. Hasil ini sama dengan hasil yang dilakukan oleh Cendrakasih (2017) yang membuktikan terdapat perbedaam bermakna pada $\mathrm{pH}$ saliva sebelum dan sesudah berkumur dengan air kelapa.

\section{KESIMPULAN DAN SARAN}

Mengkonsumsi air kelapa dapat mempengaruhi derajat $\mathrm{pH}$ saliva yaitu $\mathrm{pH}$ saliva akan mengalami penurunan. Dianjurkan tidak mengonsumsi air kelapa secara berlebihan dan meminum air mineral setelah mengonsumsi air kelapa. Perlu dikembangkan penelitian selanjutnya dengan menambah jumlah sampel, sehingga lebih mewakili populasi

\section{DAFTAR PUSTAKA}

Adzakiyah T, Lipoeto I, Kusuma N. 2016. Pengaruh berkumur larutan ekstrak siwak (Salvadora parsica) terhadap $\mathrm{pH}$ saliva rongga mulut. Sumatera Utara: Jurnal Sains Farmasi dan Klinis; hal.75.

Amalia R. 2013. Gambaran status pH dan volume saliva pada pengguna kontrasepsi hormonal di Kecamatan Mappakasunggu Kabupaten Takalar. Skripsi. Makassar: Fakultas Kedokteran Gigi Universitas Hasanuddin; hal.1,20-1.

Amerongen, A. Van Nieuw, Michels, L.F.E, Roukema, P.A, dan Veerman, E.C.I. 1991. Ludah dan Kelenjar Ludah : arti bagi kesehatan gigi. Yogyakarta: Gadjah Mada University Press.

Barlina, Rindengan. 2004. Potensi Buah Kelapa Muda Untuk Kesehatan dan Pengolahannya. Manado: Volume 3 Nomor 2, Desember 2004 : 46-60.

Hadrizaini, Ratna. 2016. Kondisi Saliva Individu Saat Berpuasa di Bulan Ramadhan. Fakultas Kedokteran Gigi. Universitas Hasanuddin. Makassar.

Hervina. 2014. Ekstrak teh hijau 3\% yang dikumur selama tiga menit lebih meningkatkan sekresi, $\mathrm{pH}$ dan kadar bikarbonat saliva dibanding satu menit dan dua menit. Tesis. Denpasar: Program Pascasarjana Universitas Udayana; hal.1-3,30.

Kusuma, Nila. 2015. Fisiologi dan Opatologi Saliva. Padang: Andalas University Press.

Kusumawardani, Cendrakasih., Leman, Michael A. dan Mintjelungan, Christy N. 2017. Pengaruh Air Kelapa Terhadap Peningkatan $\mathrm{pH}$ Saliva. Manado: Jurnal e-Gigi (eG), Volume 5 Nomor 1, JanuariJuni 2017.

Lestari F. 2015. Pengaruh pemberian air kelapa hijau terhadap tingkat nyeri haid pada mahasiswa Program Studi IImu Keperawatan STIKES 'AISYIYAH Yogyakarta. Naskah Publikasi. Yogyakarta; Program Studi IImu Keperawatan Sekolah Tinggi IImu Kesehatan 'Aisyiyah. hal.6. 
Lewapadang W, Tendean LEN, Anindita PS. 2015. Pengaruh Mengonsumsi Nanas (Ananas comusus) Terhadap Laju Aliran Saliva Lansia Penderita Xerostomia. Manado: Jurnal e-Gigi Vol 3 no 2; hal.457.

Mokoginta, Zuthra P., Wowor, Vonny N.S. dan Juliatri. 2017. Pengaruh Berkumur Air Kelapa Muda Terhadap pH Saliva. Manado: Jurnal IImiah FarmasiUNSRAT Vol.6 No.1 Februari 2017 ISSN 2303-2493.

Nuraini, Dini Nuris. 2017. Pro-Kontra Aneka Minuman Bagi Kesehatan. Yogyakarta: PENERBIT GAVA MEDIA

Prasetyo. 2002. Air Kelapa Muda Sebagai Minuman Isotonik Alami. Internet.

Runtunuwu SD. 2011. Kandungan kimia daging dan air buah sepuluh tetua kelapa dalam komposit. Buletin palma Vol 12, No 1; 2011. hal.58, 61-2.

Septiany, Cisilia. 2015. Perbedaan Kadar Imunoglobulin $\mathrm{A}(\operatorname{lga})$ Dan $\mathrm{pH}$ Dalam Saliva Akibat Pengunyahan Permen Karet Xylitol Dan Oklusi Maksimum. Fakultas Kedokteran Gigi. Universitas Hasanuddin. Makassar.

Simpala, Mawardin M. 2018. Jejak Sukses Pengusaha Kelapa Indonesia. Yogyakarta: ANDI.
Sundoro, Edi Hartini. 2007. Serba-Serbi Ilmu Konservasi Gigi. Jakarta: FK UI.

Suratri, Made Ayu Lely. 2017. Pengaruh (pH) Saliva terhadap Terjadinya Karies Gigi pada Anak Usia Prasekolah. Jakarta: Buletin Penelitian Kesehatan, Vol. 45, No. 4, Desember 2017: $241-248$.

Tarigan, Rasinta. 2014. Karies Gigi. Jakarta: Penerbit Buku Kedokteran EGC.

Vita, Dian. 2016. Kelapa Muda Pelepas Dahaga Sejuta Khasiat. Surabaya: Penerbit Stomata.

Warisno. 2003. Budi Daya Kelapa Genjah. Yogyakarta: Penerbit Kanisius (Anggota IKAPI).

Waworuntu A. 2014. Efektivitas permen karet xylitol terhadap derajat keasaman saliva setelah mengonsumsi minuman bersoda. Skripsi. Manado: Program Studi Pendidikan Dokter Gigi Fakultas Kedokteran Universitas Sam Ratulangi; hal. 35.

Yanwar SE, Sutrisno A. 2015. Minuman probiotik dari air kelapa muda dengan starte bakteri asam laktat Lactobacillus casol. Jurnal Pangan dan Agroindustri Vol 3; hal. 913 